\title{
Dimensional Imaging Sonar Damage Identification Technology Research On Sea-Crossing Bridge Main Pier Pile Foundations
}

\author{
Zhang Xuefeng1, 2,a, Li Qingning ${ }^{2, b}, \mathrm{Ma} \mathrm{Ye}^{1, \mathrm{c}}$, Jia Yongsheng ${ }^{3, \mathrm{~d}}$ \\ ${ }^{1}$ Bridge Research Center,Research Institute of Highway Ministry of Transport,china; \\ ${ }^{2}$ Civil engineering College, Xi'an University of Architecture and Technology, ,china; \\ ${ }^{3}$ Hangzhou Highway Bridge Science Technology Co., Ltd. ,china;

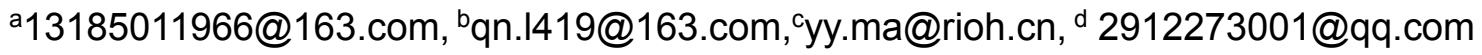

\begin{abstract}
Keywords: Sea-crossing bridge; Main pier foundations; Damage identification; Three-dimensional sonar;

Abstract.Sea-crossing bridge mostly in deep water rapids turbid waters, underwater photography traditional imaging techniques can not detect damage identification, there is no specific bridge main pier foundation damage identification technology, thus maintenance management department can not grasp the main bridge pier foundation damage situation, there is a big security risk. The present studies on a variety of underwater detection technology comparison analysis of this situation, according to bridge main pier infrastructure characteristics, proposed for main pier foundation bridge damage identification new technology based on three-dimensional imaging sonar.
\end{abstract}

\section{Sea-crossing bridge main pier foundation damage identification technology research and analysis}

At present the main techniques of underwater structures and hydraulic structures detailed detection of underwater visual inspection, imaging technology, underwater laser imaging, underwater photography, underwater sonar imaging. Underwater testing buildings technical research, according to sea-crossing bridge main pier foundation of the environment, damage detection technology comparison analysis are shown in Table 1. 
Tab.l The detection technique comparison of the main pier foundation damage

\begin{tabular}{|c|c|c|c|}
\hline $\begin{array}{l}\text { Detection } \\
\text { Technique }\end{array}$ & Advantage & Shortcoming & $\begin{array}{c}\text { Adaptability } \\
\text { Analysis }\end{array}$ \\
\hline $\begin{array}{l}\text { Underwater } \\
\text { vision } \\
\text { detection }\end{array}$ & $\begin{array}{l}\text { Having able to distinguish color, } \\
\text { stereoscopic observation, and } \\
\text { logical thinking brain linked }\end{array}$ & $\begin{array}{l}\text { We shall visit the } \\
\text { site, a large deep } \\
\text { diving, high risk, } \\
\text { high cost; not } \\
\text { produce a permanent } \\
\text { record; slow to adapt } \\
\text { to low light } \\
\text { conditions }\end{array}$ & $\begin{array}{c}\text { Not } \\
\text { applicable }\end{array}$ \\
\hline $\begin{array}{l}\text { Underwater } \\
\text { photography, } \\
\text { video } \\
\text { technology }\end{array}$ & $\begin{array}{l}\text { High-resolution images can be } \\
\text { enlarged, clearer detail, the } \\
\text { control device can be simplified } \\
\text { or adjusted in advance }\end{array}$ & $\begin{array}{l}\text { Water quality is } \\
\text { affected by the big } \\
\text { muddy, you need a } \\
\text { light source }\end{array}$ & $\begin{array}{l}\text { Water } \\
\text { turbidity not } \\
\text { applicable }\end{array}$ \\
\hline $\begin{array}{l}\text { Underwater } \\
\text { Laser } \\
\text { Imaging }\end{array}$ & $\begin{array}{c}\text { Can achieve large-area imaging } \\
\text { waters }\end{array}$ & $\begin{array}{l}\text { This technology will } \\
\text { be a lot scattered in } \\
\text { the water, energy } \\
\text { dissipation more, } \\
\text { reach an area of } \\
\text { small, clear imaging, } \\
\text { by the influence of } \\
\text { big muddy water } \\
\text { quality }\end{array}$ & $\begin{array}{l}\text { Water } \\
\text { turbidity not } \\
\text { applicable }\end{array}$ \\
\hline $\begin{array}{l}\text { Three-dimen } \\
\text { sional } \\
\text { imaging } \\
\text { sonar } \\
\text { technology }\end{array}$ & $\begin{array}{l}\text { Underwater Target contour can } \\
\text { scan imaging, is the detailed } \\
\text { structure of the underwater } \\
\text { hydraulic structures more } \\
\text { advanced means of detection, } \\
\text { water quality is not required by } \\
\text { the influence of turbidity and a } \\
\text { light source. }\end{array}$ & $\begin{array}{l}\text { Testing technology is } \\
\text { relatively more } \\
\text { difficult, need } \\
\text { professional training }\end{array}$ & $\begin{array}{c}\mathrm{Be} \\
\text { applicable }\end{array}$ \\
\hline
\end{tabular}

This study selected three-dimensional imaging sonar technology research as a Bridge Main Pier Foundation Damage detection test technique in accordance with Table 1 Main Pier Foundation Bridge Damage Detection Technology Comparison Test Analysis.

\section{Three-dimensional panoramic imaging sonar imaging technology overview}

According to the front of the Main Bridge Pier Foundation recognition technology comparison analysis, the study presents a three-dimensional imaging sonar based Bridge's main pier foundation unmanned detection technology to achieve the recognition of cross-sea bridge main pier foundation damage. In this study, three-dimensional panorama BlueView imaging sonar for a number of applications. The imaging system can not only multi-point scanning synthetic full 3D graphics software, you can also zoom in any area, in order to adopt a closer look, unusual structure, region of interest can be rotated at any angle to give the structure of three-dimensional graphics.

\section{Three-dimensional imaging sonar imaging compared with traditional test}

Site investigation found across the Bay Bridge is more deep water, flood area, traditional photographic imaging technology can not solve the Bridge Main Pier Foundation muddy water testing problems. In this paper, three-dimensional imaging sonar to address this critical technology. 
To verify whether the three-dimensional imaging sonar technology water turbidity will be affected by the impact, in turbid waters image is clear. The project selected flood of muddy water quality Caoejiang Bridge were traditional imaging method and three-dimensional imaging sonar Contrast test trials.

\section{Project Overview}

The bridge total length of $1165.3 \mathrm{~m}$, bridge span arrangement of $10 \times 20+20 \times 35+13 \times 20 \mathrm{~m}$. The bridge superstructure using $20 \mathrm{~m}, 35 \mathrm{~m}$ prestressed concrete continuous $\mathrm{T}$ beams, pile substructure using column pier.

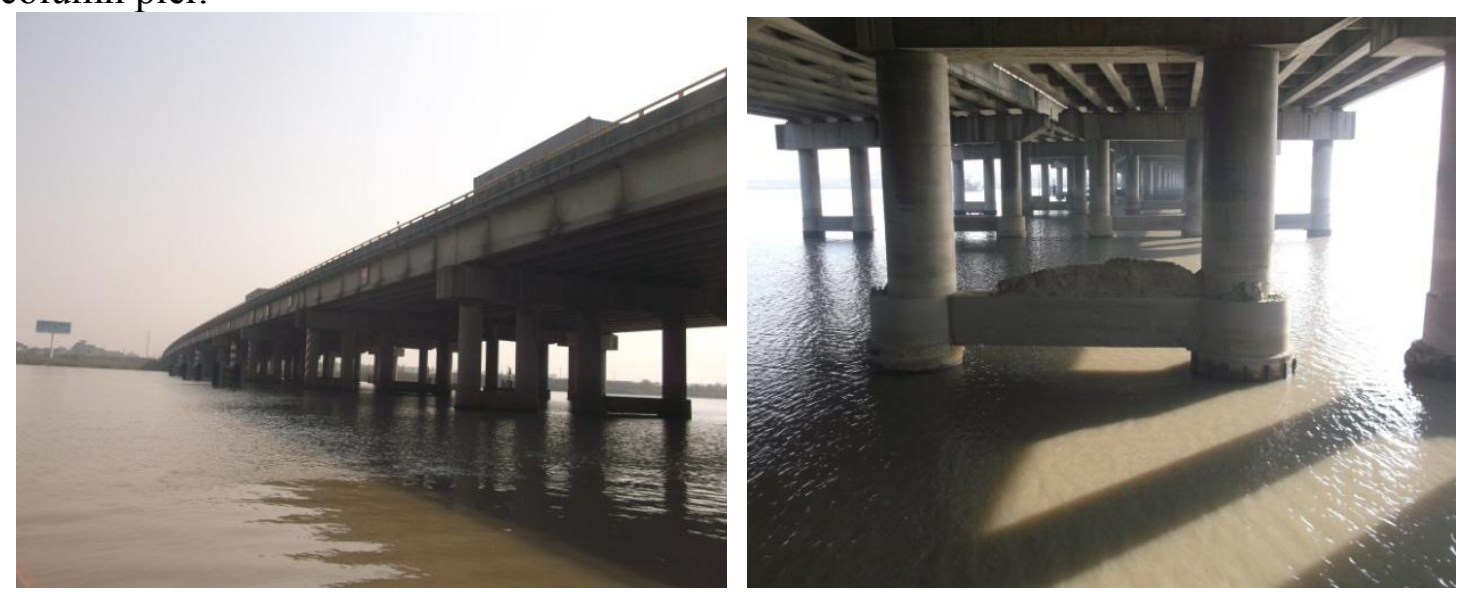

\section{Traditional imaging methods test}

Fig.1 The photo of the bridge

(1)experiment method

Divers into the water with a small hand-held tools, attachments first pile on clean surfaces to clean up after, and in the absence of eye floaters and in good condition to start recording, and finally by the testers judged according to the degree of injury pile recording results.

(2)test results

15 \# pile underwater video analysis can be seen in the surface pile Tie Beam $0 \sim 2 \mathrm{~m}$ rugged area with exposed aggregate concrete; $2 \mathrm{~m}$ to the pile surface of the riverbed area has $3 \sim 5 \mathrm{~cm}$ thick sediment cover.
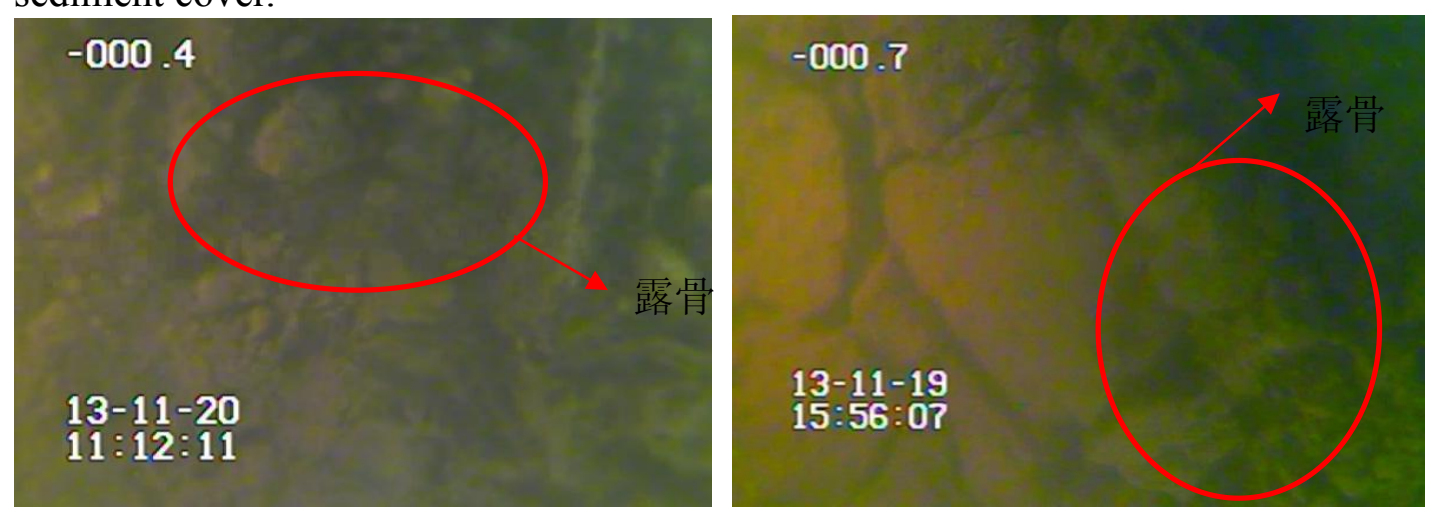

Fig.2 Right 15-1\# pile foundation, uneven concrete

\section{Three-dimensional test}

Testers use BV5000-2250Blue View three-dimensional sonar system underwater pile testing. When the scene detection, three-dimensional sonar system includes a sonar head, a laptop and a small control box. In order to verify the accuracy of the imaging system in detecting the scene also put down a good measure of the size of the anchor. Site testing Figure 3, Figure 4. 


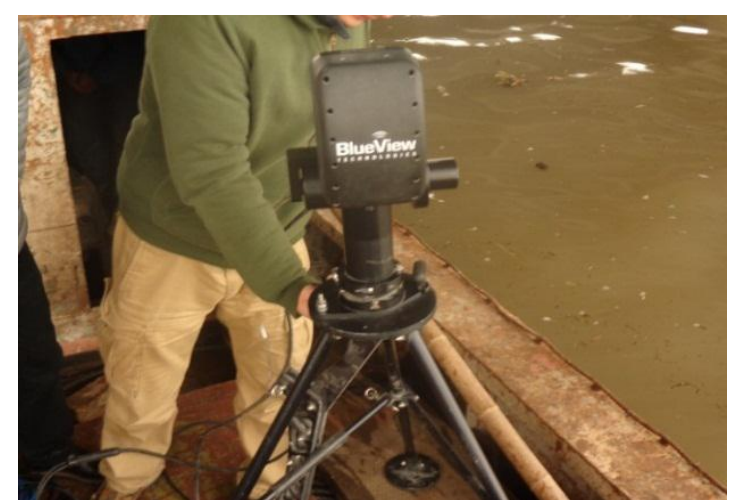

Fig.3 Sonar test on site

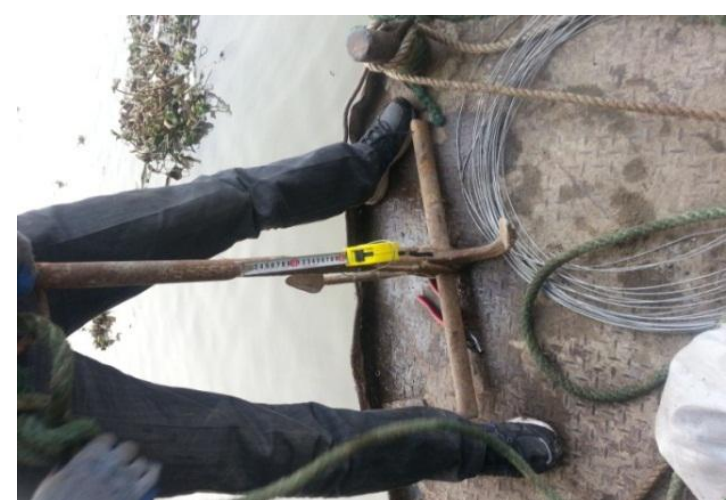

Fig.4 Comparison of anchor size

By analyzing the imaging data obtained sonar imaging shown in Figure 5, it can be seen from the figure Pile image is very clear, it is clear that the existing bridge is in good condition overall underwater pile, locally explicit phenomenon, surface uneven, but has little effect on the overall structure, used for verify the accuracy of the maximum diameter of the anchor $1.5 \mathrm{~cm}$, the minimum diameter of $1.0 \mathrm{~cm}$, the figure from the imaging to be clearly identified, indicating that the accuracy of the imaging device can be achieved $1.0 \mathrm{~cm}$.

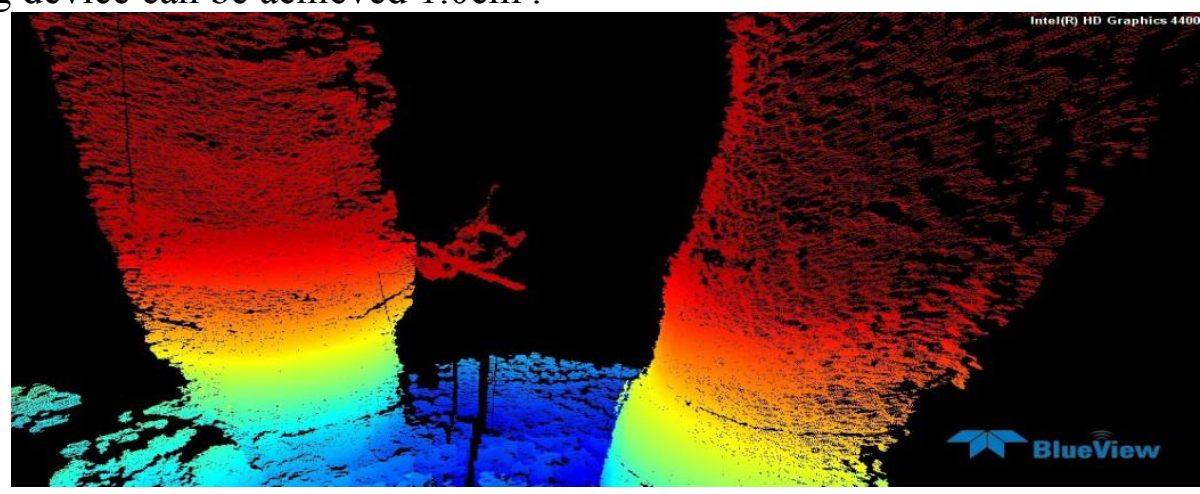

Fig.5 Analysis result of imaging sonar

\section{Conclusions}

Through this three-dimensional imaging sonar technology with traditional photographic imaging field compared to the test, let us more insight into the characteristics of three-dimensional imaging sonar imaging, test results showed that:

(1)Three-dimensional imaging sonar from water turbidity affected. Compared to the results of underwater cameras, sonar systems analysis results are not three-dimensional underwater visibility influence to obtain a fine image;

(2)Three-dimensional imaging sonar test range. Underwater cameras can only capture a small range of pile test local image, compared to three-dimensional imaging sonar underwater camera can not only get a partial extent of the damage, but also the overall situation observed pile;

(3)Three-dimensional imaging sonar testing high precision. By measuring the size of a good anchor imaging results showed that three-dimensional imaging sonar testing precision can reach $1 \mathrm{~cm}$, with the increase of three-dimensional imaging test frequency sonar, which will gradually increase the accuracy of the test, to meet the main pier foundation Bridge damage identification requirements.

\section{References}

[1] Zhang Tiedong.Research on post image processing algorithms a front view Sonar [D]. Harbin Engineering University, 2004.

[2] Yang zhi, Wang Jianzhong, Fan Hongxia. Three-dimensional panoramic underwater imaging sonar system in detail Structure Testing [J]. Water Resources and Power, 2015, 33 (6): 59-62. 
[3] Yu S C, Kim T W, Marani G, et al. Real-time 3D sonar image recognition for underwater vehicles[C]//Underwater technology and workshop on scientific use of submarine cables and related technologies, 2007. Symposium on. IEEE, 2007: 142-146.

[4] Belcher E O, Lynn D C, Dinh H Q, et al. Beamforming and imaging with acoustic lenses in small, high-frequency sonars[C]//OCEANS'99 MTS/IEEE. Riding the Crest into the $21 \mathrm{st}$ Century. IEEE, 1999, 3: 1495-1499.

[5] Verbeek P P, Slob A. User behavior and technology development[M]. Springer, 2006.

[6] Ferréol A, Larzabal P, Viberg M. On the asymptotic performance analysis of subspace DOA estimation in the presence of modeling errors: case of MUSIC[J]. Signal Processing, IEEE Transactions on, 2006, 54(3): 907-920.

[7] Belcher E O, Barone J R, Gallagher D G, et al. Acoustic lens camera and underwater display combine to provide efficient and effective hull and berth inspections[R]. WASHINGTON UNIV SEATTLE APPLIED PHYSICS LAB, 2003.

[8] Pesavento M, Gershman A B, Haardt M. Unitary root-MUSIC with a real-valued eigendecomposition: A theoretical and experimental performance study[J]. Signal Processing, IEEE Transactions on, 2000, 48(5): 1306-1314.

[9] Yang L, Taxt T. Multibeam sonar bottom detection using multiple subarrays[C]//OCEANS'97. MTS/IEEE Conference Proceedings. IEEE, 1997, 2: 932-938. 